\title{
The Earth Sciences in Unesco
}

\author{
by Vladimir Šibrava
}

The United Nations Educational, Scientific and Cultural Organization has a large and extremely varied program in the earth sciences. This includes IGCP, which is regarded as one of the most successful international programs in any science today. Indeed, even the U.K. and the U.S.A., which have recently withdrawn from membership in Unesco, continue to support IGCP financially through IUGS. Unesco's earth science activities are carried out through a complex network of cooperative arrangements with other UN organizations, and with national and regional bodies, governmental and non-governmental alike; IUGS is one of its major partners. The Director of the Division of Earth Science here surveys Unesco's many activities in geoscience. (Ed.)

\section{Int roduction}

The present Unesco program in earth sciences is based on consultations with Member States and international seientific organizations, such as IUGS and IUGG (for explanation of acronyms and abbreviations used in this article see Table 1). The implementation of the program and its scientific results are evaluated by independent scientific bodies and reviewed by the Unesco Executive and at its General Conference.

Unesco's geoscience programs are managed by the Division of Earth Sciences in Paris, in cooperation with Regional Offices in Nairobi, New Delhi, Jakarta, Montevideo, Amman and a representative of fice in Beijing (Table 2). However, some activities related to marine geology are handled by the Division of Marine Sciences and by the IOC, whereas those related to groundwater are dealt with by the Division of Water Sciences. The interdisciplinary character of some activities requires increasingly close cooperation with other parts of Unesco, such as the Division of Ecological Sciences, which is responsible for the MAB Program, and the Cultural Heritage Division in the Sector of Culture and Communication (this is in connection with the Natural Ilazards program).

Unesco's two main geoscience programs are "The Earth's Crust and its Mineral and Energy Resources" and one aimed at the study of natural hazards. The former includes the IGCP, a major regional project entitled "Geology from Development," research on the dissemination of geological data, the production of geological maps, and a series of post-graduate training courses. Each of these is reviewed in the following.

\section{International Geological Correlation Programme}

A joint venture between Unesco and IUGS, IGCP is considered to be one of the most successful international scientific programs in the geological sciences. Now in its 16 th year, IGCP attracts interest and cooperation from hundreds of scientists all over the world. There are about 50 scientific projects running every year, most lasting five years, with some as long as a decade. IGCP covers a wide range of scientific topics from traditional and event stratigraphy (Fig. 1), paleontology, petrography, geochemist ry, economic geology, to laboratory methods, computer applications and remote sensing. The results and proposals for

\section{TABLE 1}

Acronyms Used in this Article

\begin{tabular}{|c|c|}
\hline CEMW & Cormission for the Geological Map of the World \\
\hline IFEG & $\begin{array}{l}\text { Centre International pour la Formation et les } \\
\text { Echanges Géologiques }\end{array}$ \\
\hline CODATA & ICSU Committee on Data for Science and Technology \\
\hline GARS & Geologic Applications of Remote Sensing \\
\hline IAEA & International Atomic Energy Agency \\
\hline IASPEI & $\begin{array}{l}\text { International Association of Seismology and } \\
\text { Physics of the Earth's Interior }\end{array}$ \\
\hline I GCP & International Geological Correlation Programe \\
\hline IHP & International Hydrological Programme \\
\hline ILP & International Lithosphere Program \\
\hline INQUA & International Union for Quaternary Research \\
\hline $10 \mathrm{C}$ & Intergovernmental Oceanographic Cormission \\
\hline IUGG & International Union of Geodesy and Geophysics \\
\hline IUGS & International Union of Geological Sciences \\
\hline MAB & Man and Biosphere \\
\hline UNDP & United Nations Development Programe \\
\hline UNDRO & United Nations Disaster Relief Organization \\
\hline JEF & UN Environment \\
\hline Unesco & $\begin{array}{l}\text { United Nations Educational, Scientific and } \\
\text { Cultural Organization }\end{array}$ \\
\hline WOVO & World Organization of Volcano Observatories \\
\hline
\end{tabular}

new projects are assessed annually by the IGCP Scientific Committee and the Board, the members of which are jointly nominated by IUGS and Unesco. The Committee is chosen on the basis of specialization in geological sciences whereas the Board is selected more for regional representation.

The progress of IGCP is reported in the bulletin Geological Correlation, published by Unesco each year, in English and French. The scientific achievements are also reflected in numerous scientific journals and monographs (e.g. Berglund, 1986; Beus, 1986; Cook and Shergold, 1986; Hein, 1987; Petrascheck et al., 1986; Reyment and Bengston, 1986; Sibrava et al., 1986, and van de Plassche, 1986), Unesco's science quarterly publication Nature and Resources also carries regular items about IGCP, as, of course, does Episodes. Three catalogues of IGCP publications have now been released by Unesco. The first one, comprising 4,737 publications over the period 1973-1979, was published in 1980; the second one, attaining the number of 14,539 publications, covered the period 1978-1982. The last catalogue, edited in 1986, for 1983 to 1985 (published in 1986) brings the list to 17,758 publications on or about IGCP projects. Some examples of monographs that have recently appeared are given at the end of this article.

Scientific evaluations of IGCP have been published as special blue-covered editions of Geological Correlation. The first "blue book" assessed the scientific achievements between 1973 and 1977 (Bassett, 1978), and the second, covering the period 1978-1982, appeared in 1983. A third is now being prepared for printing and should be released by the end of 1987 . 
TABLE 2: Some Key Addresses for Unesco

At Unesco Headquarters (7, place de Fontenoy, 75700 Paris, FRANCE)

- Division of Earth Sciences (Director - V. Šibrava)

- IGCP Secretariat (Secretary - E. Dudich)

- Division of Water Sciences (Director - S. Dumitrescu)

- Division of Marine Sciences (Director - D. Krause)

- Intergovernmental Oceanographic Commission - IOC (Secretary - M. Ruivo)
Division of Ecological Sciences (for MAB; Director B. von Droste zu Hulshoff)

Cultural Heritage Division (for Natural Hazards; Director - A. Raide)

\section{Regional offices}

Regional office of Science and

Technology for South and Central Asia (ROSTCA)

15 Jor Bagh

New Delhi - 110003 , INDIA

Regional office for Science and

Technology for Africa

(ROSTA)

P.0. BOX 30592

Nairobi, KENYA
Regional office for Science and Technology for the Arab States (ROSTAS)

8 Abdel Rahman Fahmy St.

Garden City

Cairo, EGYPT

Regional office for Science and

Technology for Southeast Asia

(ROSTSEA)

J1. Thamrin 14 - Tromolpos 273/JKT

Jakarta, INDONESIA
IGCP has brought together scientists from many different parts of the world and has succeeded in mobilizing geoscientific potential of many countries, as well as important national financial contributions. The IGCP activities spread out to many developing countries, and scientists from the Third World are taking a substantial part in this program (Fig. 2). More than 2,000 scientists now participate in IGCP, and national committees have been established in 83 countries. IGCP now aims to increase its interdisciplinary links with other international scientific programs, such as ILP, IHP, MAB and IOC.
At its last session in February 1987, the IGCP Board endorsed a proposal for a new subprogram entitled "Quaternary Geosciences and Human Survival." This will focus on the study of the Quaternary Period and the practical applications in economic geology, ag riculture, paleoclimatic studies and prediction of climatic changes, as well as on environmental studies. The bulk of these activities are already being carried out in existing IGCP projects, but new regional projects are foreseen as well, and the training component, especially for developing countries, will also be an important component. This subprogram will also bring a
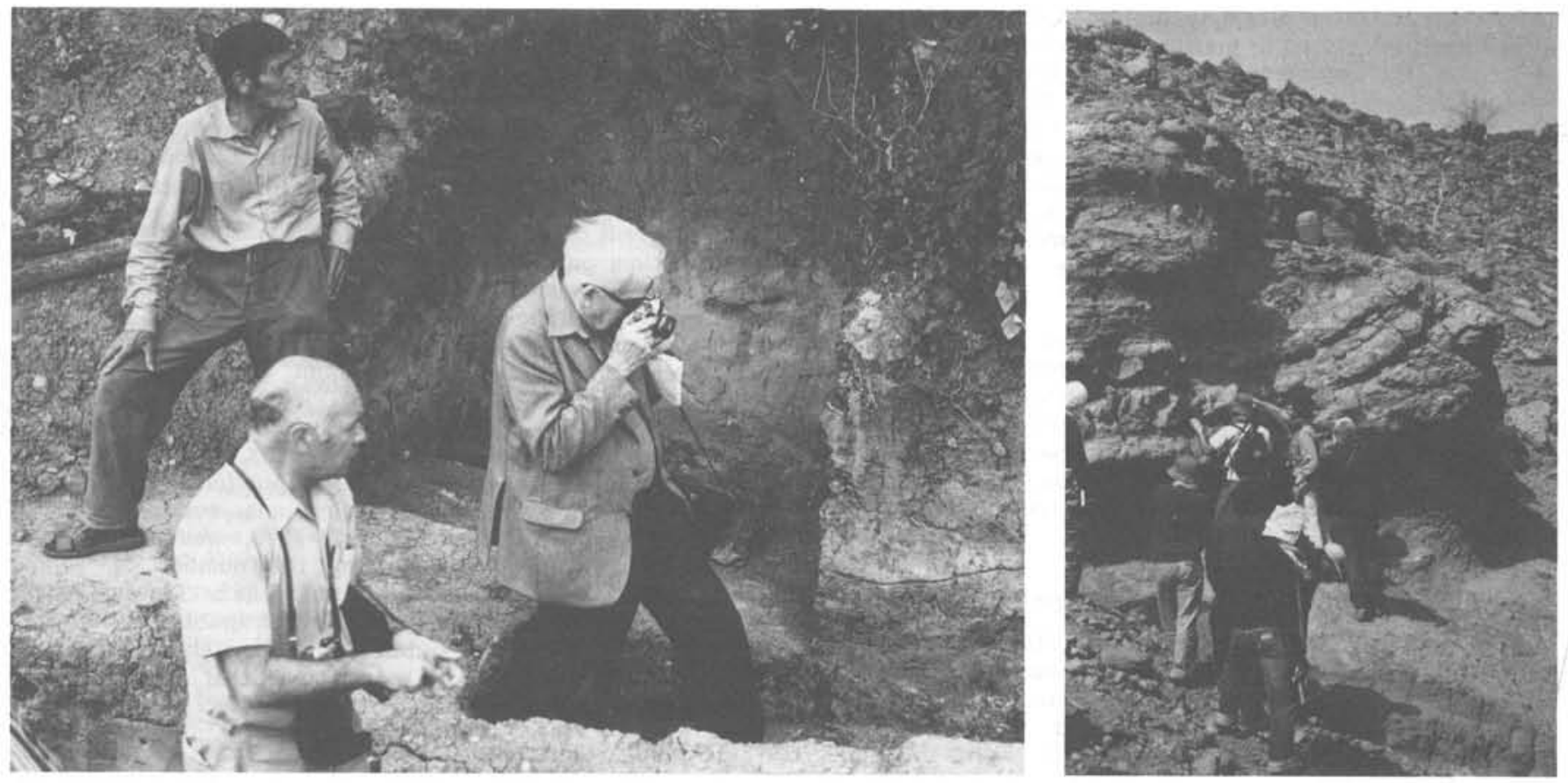

Figure 1: Examining the section Dolni Vestonice, Czechoslovakia. Field trip during the meeting of the IGCP Project 24 "Quaternary glaciations in the Northern Hemisphere", Ostrava, Czechoslovakia, 1979.
Figure 2: Participants in the Unesco-IGCP symposium, Till Mauritania, 1983, studying the Precambrian tills at the exposure Guell Nuatil. 
geoscientific input to the International Geosphere-Biosphere Program. Indeed, Unesco has already co-sponsored a meeting in Dakar in 1986, on Global Changes in Africa, organized in cooperation with INQUA. An IGCP regional meeting was held in July 1986 in Jakarta to set up a program for basic and applied Quaternary studies in Southeast Asia.

\section{"Geology for Economíc Development"}

In 1980, the General Conference of Unesco authorized the creation of several major regional projects in various fields of activities. Among them was one entitled "Geology for Economic Development." The project is presently aimed at the study of African Precambrian, through specially organized geotraverses (Fig. 3). It also entails the postgraduate training of African geologists in Precambrian geology, economic geology and mineral prospecting, mining geology and the application of remote sensing methods. There is also a component aimed at the strengthening of African geological institutions. This includes, in particular, the development of their laboratories and laboratory research, and cooperation with non-African industrialized countries (Fig. 4).

A specific objective is to promote South-South scientific cooperation through joint studies in Africa and South America. These are aimed at comparative research on Lower Proterozoic formations and, in particular, the greenstone belts of both continents. In 1987, it is planned that two African geologists will participate in field work in Brazil; likewise, Latin American scientists will take part in field research in Africa.

Unesco has contributed to the development of a geochronological laboratory in Harare, Zimbabwe, which is using $\mathrm{Rb} / \mathrm{Sr}$ techniques and which offers training for African geologists in geochronological analysis. Samples analyzed so

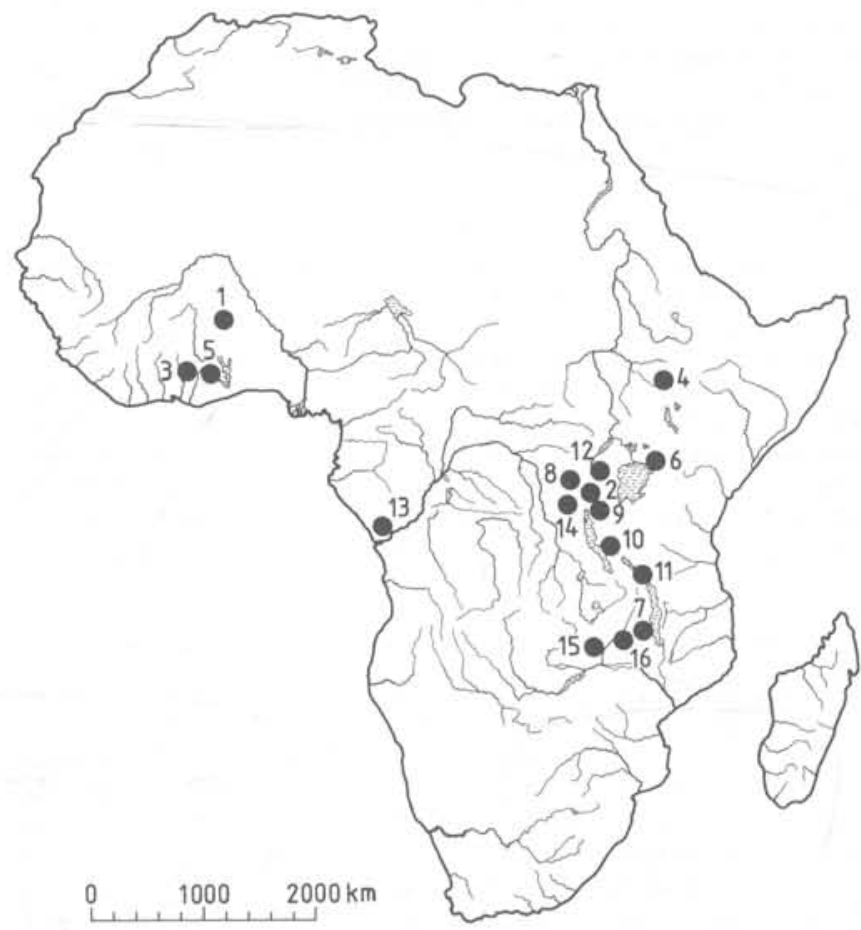

Figure 3: Location of geotraverses sponsored by Unesco in Africa. 1 - Burkina Faso to Togo, 2 Burundi, 3 - Ivory Coast, 4 - Ethiopia, 5 - Ghana, 6 - Kenya, 7 - Malawi, 8 - Rwanda, 9, 10, 11 Tanzania, 12 - Uganda, 13 - Zaire (Bas Zaire), 14 Zaire (Kivu), 15, 16 - Zambia.

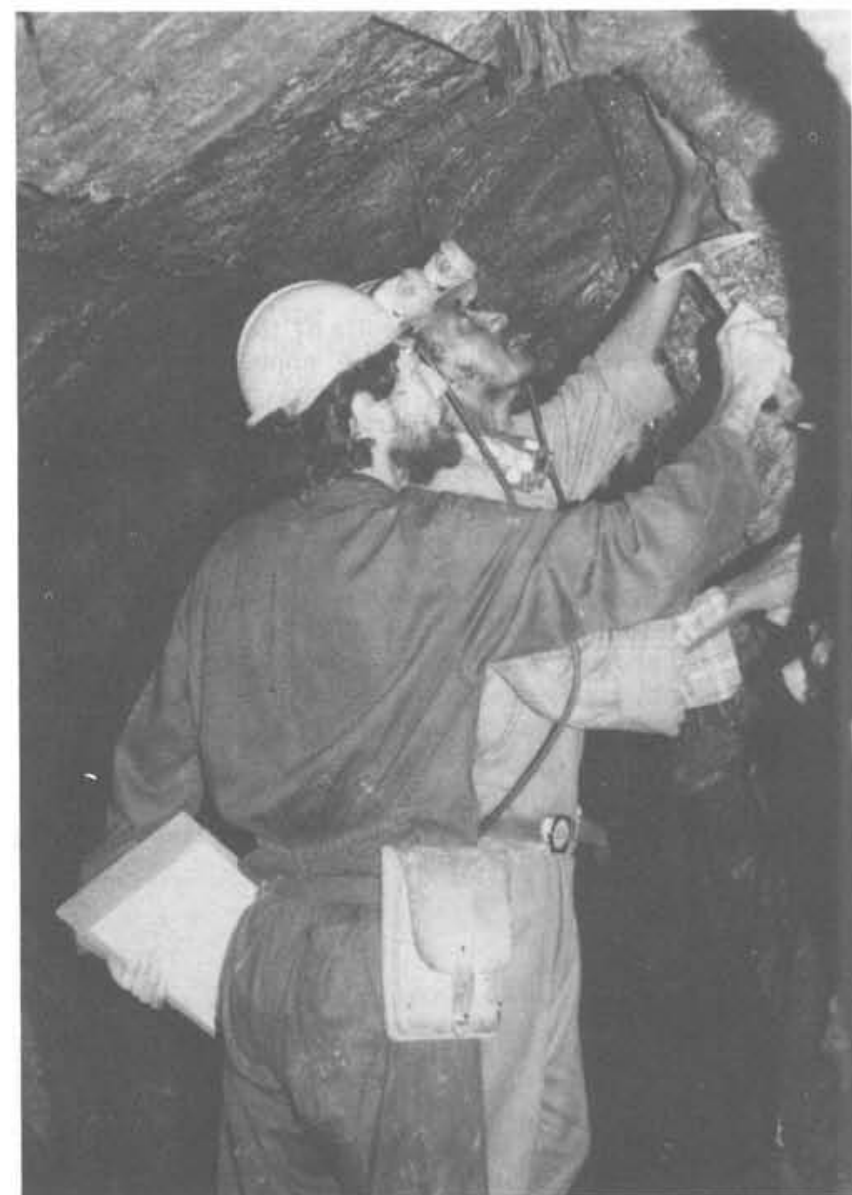

Figure 4: Unesco training course in mining geology in Zimbabwe, 1985. Participants Mario Deus (Mozambique) and Aberra Getahun (Ethiopia) studying the geology in the Nando-Pinkun gold mine near Kadoma, zimbabwe.

far are from the Lower and Middle Proterozoic of Africa, in particular the granulites of the Uluguru Aountains in Tanzania (Mozambique belt), and the basement syenites and post-orogenic granites of central and southern Malawi.

Field research is now concentrated on the Kibaran mobile belt of East, Central and southern Africa, and on the Birimian of West Africa. A conference on the Kibaran, organized by Unesco in Bujumbura, Burundi, in October 1983 , contributed to the exchange of scientific knowledge among participants of many African countries, since they had very little chance otherwise of comparing their observations. The Kibaran belt and adjacent mobile zones have been studied in Zambia (the Irumide belt and the Lufilian arc), Tanzania (the Ukingan and Ubendian belts), Malawi and Ethiopia (the Mozambique mobile zone), and Uganda (the Kibaran belt of southwest Uganda). In Zaire work has focussed on the tectonic and magmatic evolution of the Precambrian.

In 1983, studies were initiated in West Africa by the implementation of geotraverses in Burkina Faso and Togo, investigating the geology and metallogenesis of the Eburnean and Panafrican. These were followed by field studies in the Birimian of western Ghana and the Ivory Coast. Research teams participating in the fieldwork included geologists from both French- and English-speaking A frican countries, for one objective is to resolve differences in terminology and approach to the stratigraphic interpretation of the Birimian between francophone and anglophone 
countries. A report of a meeting held in late 1986 in Abidjan will soon be published, with basic definitions of the Birimian and English and French terminology.

In 1987, geotraverses were scheduled for the Lupa goldfield in the Mbeya region of southwest Tanzania, focusing on the study of gold mineralization and tectonic evaluation of the Lupa block, and for Nyanza Shield around Lake Victoria in Kenya. The location of geotraverses in West Africa is under examination.

To report on the activities and results of this project Unesco publishes in French and English an annual newsletter of which five issues have so far appeared. Free copies are available from the Division of Earth Sciences and from the Nairobi Regional Office (see Table II).

In cooperation with the Museum of Central Africa in Tervuren, Belgium, and with CIFEG in Paris (see accompaning article - Ed.), Unesco co-publishes a continuing bibliography of African geological literature entitled Géologie africaine - African Geology. Within the framework of this project, Unesco also facilitates the participation of scientists from developing countries in scientific projects, congresses and symposia held in industrialized countries.

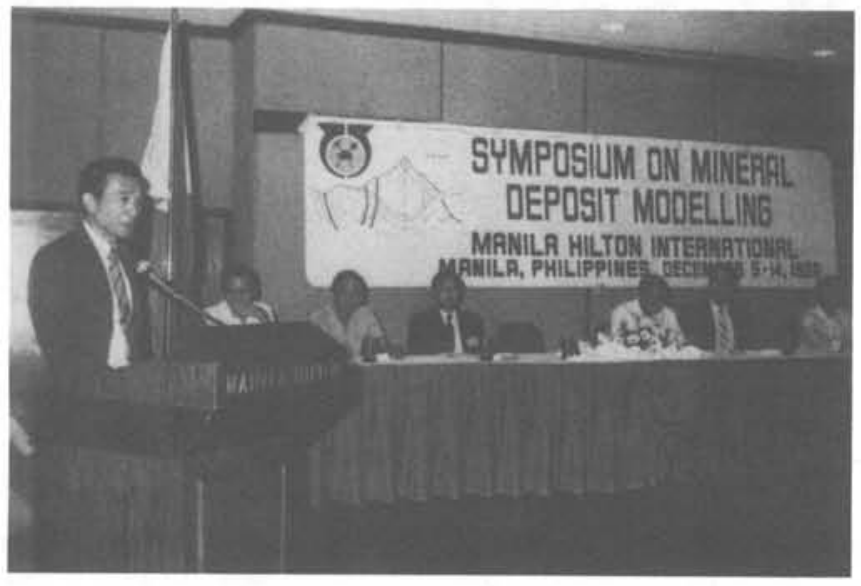

Figure 5: ESCAP-IUGS-Unesco workshop on mineral deposit modelling in Manila, Philippines, 1985.

\section{Disseminating Geological Data}

Unesco also works in the fields of geology and land-use planning, geological application of remote sensing, resource modelling and the preparation and publication of geological maps. Geology and land-use planning is aimed at the study of geological, geochemical and geophysical factors influencing the environment. These activities are coordinated with the joint Unesco/UNEP project "Geology and Environment," which succeeded a similar one entitled "Lithosphere as a component of the environment" dealing mostly with hydrological problems. The current project is focussed on geology and land-use planning, the impact of water management on the lithosphere, and mining activities and the environment. Unesco has co-published with IAEA a book on geology and waste disposal (Cidlinsky, 1985), and one published this year (Unesco, 1987) deals with the general geological aspects of environmental studies. In the near future, Unesco will develop the training component of this project.

A joint Unesco/IUGS project "Geological Application of Remote Sensing" (GARS) was launched in 1984 with priority areas in East Africa and Latin America. In Africa, these studies are coordinated with the "Geology for Economic Development" project described earlier. The first phase of GARS evaluated the Karema area in Tanzania (Ubendian zone at the western margin of the Tanzanian craton) by means of Landsat TM imagery (see CODATA, 1986, for the background to this project), and further studies are foreseen in Burundi using Landsat TM and SPOT imagery. The second phase will focus on the study of remote sensing methods in tropical areas with a dense vegetation cover in Latin America. Another joint IUGS/Unesco activity is the resource modelling program, described elsewhere in this issue. This involves regional workshops on mineral deposit modelling (Khartoum, 1985; Manila, 1985 (Fig. 5); Belo Horizonte, 1986; Chile, 1987), with results published occasionally in a joint IUGS-Unesco newsletter.

\section{Geological Maps in Unesco}

Unesco publishes, in traditional cooperation with CGMW small-scale geological maps. Among those printed over the last few years are the Geological World Atlas (at $1: 10,000,000$; ocean sheets $1: 36,000,000$ ) completed in 1986 with 22 sheets, the International Geological Map of Europe $(1: 2,500,000)$, with completion foreseen in 1988 , and the Metallogenic Map of Europe. In 1986, the metallogenic and metamorphic maps of Southeast Asia $(1: 5,000,000)$ were published, as were the Seismotectonic Map of Iran, Afghanistan and Pakistan $(1: 5,000,000)$ and two sheets of the new edition of the Geological Map of Africa $(1: 5,000,000)$. In preparation for printing are the first sheet of the new Map of Mineralization of Africa $(1: 5,000,000)$, the Geological Map of the World $(1: 25,000,000)$, the Geological Map of South America and Southeast Asia $(1: 5,000,000)$ and the Metamorphic Map of South America at the same scale. Further information on geological maps are given in the Unesco and CGMW eatalogues of publications.

\section{Unesco-sponsored Postgraduate Training Courses in Earth} Sciences

Postgraduate training in earth sciences constitutes an important part of Unesco's activities, and courses are aimed especially toward participants from developing countries. Courses organized with the cooperation and important financial support of host countries cover general geology, metallogeny, tectonics, mineral and geochemical prospecting, volcanology, geophysics, seismology, mining geology, geothermal energy and remote sensing. In 1986, 20 courses and seminars took place, and more than 350 scientists profitted from the training.

The training period is mostly from four to eight weeks, but some training courses last up to two years. To quote only three examples there are a seven-month course on geothermics organized annually in Pisa, Italy, by the International School of Geothermics of the International Institute for Geothermal Research, one on geochemical prospecting methods organized by the Geological Survey of Czechoslovakia, and one on metallogeny at the Central University of Quito, Ecuador. A full list is included in each issue of Episodes, and all National Commissions for Unesco are directly informed by the Unesco Secretariat.

\section{Unesco's Program on Natural Hazards}

The origin of Unesco's program on natural hazards dates back to the 30th Session of the United Nations Economic and Social Council in July 1960, which adopted a resolution requesting the cooperation of Unesco and the specialized agencies of the United Nations to prepare a comprehensive study on ways and means of reducing damage and loss of life from earthquakes. The activities in this field started in Unesco the following year and were initially concerned with basic seismology. Unesco's activities were later extended to the reduction of earthquake risk and to other categories of natural hazards of geological and geophysical origin, such as volcanic eruptions, landslides and tsunami.

Within the framework of this program, Unesco participates in the establishment of international and regional centres for the exchange and analysis of data, promotes research on 
disaster-prone areas with regard to assessment of earthquake risk, and undertakes field studies of the effects of large earthquakes, volcanic eruptions and landslides. As in the field of geology, training activities in natural hazards represent an important element in the program, and there are specialized training courses and seminars.

For the implementation of this program, Unesco cooperates with international non-governmental scientific organizations, such as IASPEI, the International Association of Earthquake Engineering, as well as UNDRO and UNEP. Unesco contributes, for example, to the publication of the periodical bulletin Felt and Damaging Earthquakes, edited by the International Seismological Centre in the U.K.

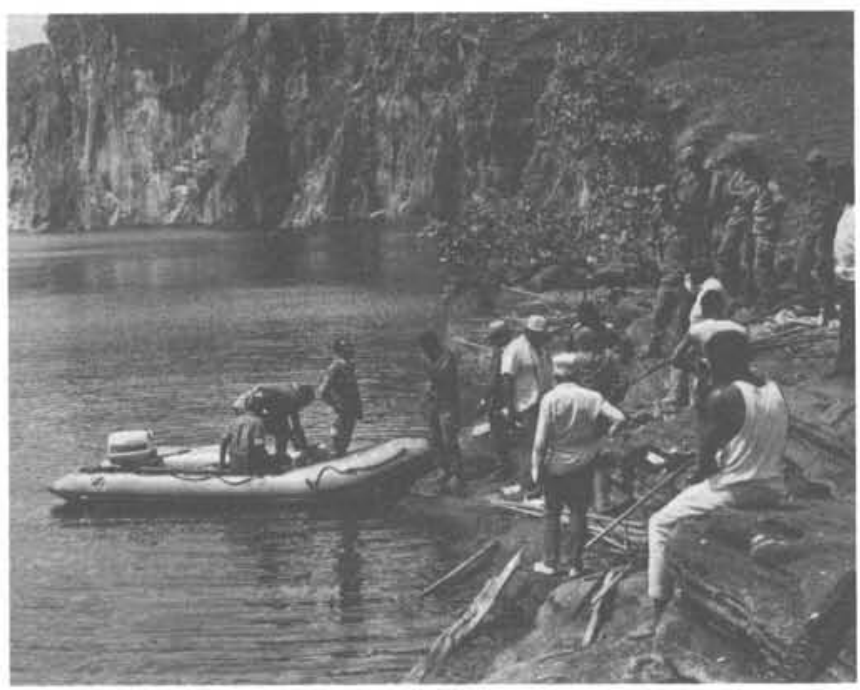

Figure 6: Unesco acted as executing agency for the International Conference on the Lake Nyos disaster. Scientists here prepare to study the lake.

Unesco is also involved in and has contributed to the development of seismic networks in regions such as Southeast Asia, Central Asia, the Balkans and the Arab states. It collaborates with international centres in Japan (e.g. the International Institute of Seismology and Earthquake Engineer ing) and the regional centres in South America (Centro Regional de Sismologia para America del Sur, Peru) and Yugoslavia (Institute of Earthquake Engineering and Engineering Seismology, Skopje), and with numerous national centres and institutions. In most of these activities, including training and the establishment of centres and observation networks, Unesco has served as the executing agency for projects funded by UNDP.

Since the very beginning of this program, Unesco has been entrusted with earthquake reconnaissance missions to disaster-affected areas upon request of Member States. Between 1962 and end of 1987, these missions have studied the effects and mechanisms of many disastrous events, mainly earthquakes, and have contributed significantly to our knowledge of seismicity and seismic hazards in Anatolia, Iran, Venezuela, India, Yugoslavia, Philippines, Peru, Chile, Colombia and Guinea. New information has been brought to light, for example, on seismotectonics and the relationship between earthquakes and large-scale landslides in Peru. The data obtained have improved the knowledge of behaviour of local types of buildings and of modern constructions under dynamic loading, and this information has contributed to the upgrading and revision of regulations for earthquakeresistant design as well as for the restoration of housing in earthquake-affected areas, and the reconstruction of historical monuments.
From 1962 to 1987, Unesco organized 29 such missions, some of which resulted in the creation of new projects and activities aimed at the reduction of risks in earthquakeprone areas. Other projects dealing with natural hazards were introduced into Unesco's program at the request of Member States or international agencies. Thus, after the El-Asnam earthquake in Algeria, a project on the microzoning of the Ech-Chlef area was introduced with the assistance of UNDP and Unesco (see Weber, 1981).

At the request of the Arab Fund for Economic and Social Development and the Islamic Bank, Unesco published in 1984 a feasibility study for the "Program for the Assessment and Mitigation of Earthquake Risk in the Arab Region." This project, which is now being implemented, involves the study of earthquake risk assessment and reduction, training of technical personnel and the application of earthquake risk reduction measures. At the present time, the project represents one of the most ambitious regional seismological projects implemented with the involvement of Unesco. Another project, dealing with the improvement of the seismological network in Vietnam and financed by UNDP is now underway.

At its General Assembly in Tokyo in August 1985, IASPEI adopted a resolution seeking cooperation with Unesco in investigating the possibility of creating a seismic network in Africa. IASPEI and Unesco, with the participation of the joint IUGS-IUGG Inter-Union Commission on the Lithosphere, established a working group on "Seismological Recording and Earth Science Studies in the African Continent." The aim is to assist in the creation of a national seismic network and service system and to coordinate activities on a regional scale. The first working group meeting was held in November 1986 at Unesco Headquarters, and the second in Vancouver in association with the 1987 IUGG Assembly.

After the disastrous outburst of toxic gas in Lake Nyos in Cameroon in August 1986, Unesco, in cooperation with the Economic Commission for Africa, was entrusted with the preparation and organization of an international conference, convened at the request of the government of Cameroon. The conference was held in Yaounde from 16 to 20 March 1987, and summarized important data on the geological, geophysical, biological, medical and social aspects of the disaster (Fig. 6). Even if some problems relating to the exact cause of the disaster still persist, specific recommendations for actions to be undertaken have been transmitted to the Cameroonian Government, and this new type of natural disaster is to be studied in the future.

Unesco is also engaged in the study of volcanic activities and landslides. In cooperation with UNEP, Unesco conducted from 1982 to 1984 a preparatory study for the program "International Mobile Early Warning System for Volcanic Eruptions," to facilitate mutual assistance and to assist in coping with volcanic crises, and to investigate potentially dangerous volcanoes. Under this program, Unesco, in cooperation with WOVO (Sigvaldason, 1981), has dispatched missions at times of volcanic crises to Nevado del Ruiz (Colombia) and Mount Tacana (Mexico). Unesco and WOVO publish jointly the Directory of Volcano Observatories (available from the Nordic Voleanic Institute, University of Iceland, Reykjavik, Iceland) with data resulting from activities of this program. Several other publications dealing with different types of natural hazards have also been published by Unesco, such as avalanches (Unesco/IAHS, 1981), landslides (Varnes, 1984) and voleanic eruptions (Crandall et al., 1984; UNDRO/Unesco, 1985).

Unesco's activities in the field of natural hazards have been recently evaluated by an independent body of experts who recommended strengthening the program and setting up a horizontal structure in order to ensure interdisciplinary cooperation. They also stressed the cultural, education and social aspects of natural hazards. 


\section{Other Geological Activities in Unesco}

The organization's activities related to groundwater are dealt with by the Division of Water Sciences; many of these are under the aegis of the IHP. These include methodological aspects, such as studies on the role of groundwater in hydrological cycle and water balances, compilation of a world map on groundwater flow, and preparation and publication of a handbook on legends for hydrological maps.

Groundwater research represents a part of regional hydrological projects in arid and semi-arid regions, mountain areas, humid tropical zones, karstic areas, and small islands. The Division is involved in the preparation of hydrogeological maps of Africa, Central America and Mexico and a hydrogeological atlas of the Caribbean. Groundwater is, of course, dealt with in the framework of general hydrological training, or is taught in special training courses such as one on groundwater hydrology for arid regions organized in Cairo, and on groundwater tracing techniques in Austria.

The Division of Water Sciences has published many books and documents in the area of groundwater (e.g. Unesco, 1984). These include topics on groundwater studies, aquifer contamination and protection, land subsidence due to groundwater pumping, sub-surface water in hard rocks, and groundwater contamination and methods for its protection.

Marine geology is covered by Unesco's program on the ocean and its resources. This is implemented jointly by the IOC and Unesco's Division of Marine Sciences. Many activities under the Regular Program of Unesco also include activities on the geological aspects of marine science, particularly on nearshore geology. Some of the activities under the IOC Program on Ocean Sciences in Relation to Non-Living Resources are linked with activities of the IGCP. For example, there are several projects dealing with marine geology (e.g. 156 - Phosphorites, and Project 200 - Sea-level Correlations and Applications), and others are related to geological mapping, tectonic studies and studies in environmental changes.

The IOC, in collaboration with the International Hydrographic Organization and the Canadian Hydrographic Services, has published the fifth edition of the General Bathymetric Chart of the Oceans (GEBCO) consisting of 18 sheets, the major map of global ocean topography. The IOC is also involved in the preparation of global and regional geological and geophysical charts (e.g. regions of the Pacific, Atlantic, Mediterranean, Caribbean and eastern central Atlantic).

Also within the IOC framework is the International Tsunami Warning System, which provides services to Member States in the Pacific and assistance for the training of specialists in tsunami direction and warning. The Division of Marine Sciences cooperated closely with the Division of Earth Sciences in the preparation and publication of ocean sheets of the Geological Atlas of the World.

The activities of the Earth Sciences Division also have a close link to the MAB Program, implemented by the Division of Ecological Sciences. Although the focus here is on ecology, topies on environmental studies, erosion, desertification and other areas of common interest for both Divisions require close cooperation and integrated interdisciplinary approach.

\section{Conclusion}

The activities in earth sciences that are described in this paper are based on Unesco's Medium Term Plan of activities for 1984-1989. The regular annual budget of the Division of Earth Sciences is currently around $\$ 1$ million US. Of this about $37 \%$ goes to IGCP, and $25 \%$ to the natural hazards program. A new Medium Term Plan for the years 19901995 is now under preparation and will be discussed at the next Unesco General Conference. Comments from Member States on this Plan should reflect new directions in world geology and influence Unesco's programs accordingly.

Dr. V. Šibrava has been Director of the Unesco Division of Earth Sciences (7, place de Fontenoy, 75700 Paris, France) since 1981. A Quaternary geologist, he was the leader of the IGCP Project 24 "Quaternary Glaciations in the Northern Hemisphere," Chairman of the INQUA Commission on Quaternary Stratigraphy, VicePresident, and from 1973 to 1977 President of INQUA. He was Director of the Geological Survey of Czechoslovakia in Prague from 1970 to 1978 .

\section{References}

Bassett, M.G. (ed.), 1978. International Geological Correlation Programme Scientific Achievements 1973-1977. Geological Correlation, Special Issue. Unesco, Paris, 120p.

Berglund, B.E. (ed.), 1986. Handbook of Holocene Palaeoecology and Paleohydrology. John Wiley, 750p.

Beus, A.A., (ed.), 1986, Geology of Tungsten. Earth Science, v. 18, Paris, 280p.

Cidlinsky, K. (ed.), 1985. Geoenvironment and Waste Disposal. Unesco, Paris, 296p.

CODATA, 1986. Methodology for Multisatellite Thematic Mapping. CODATA Bulletin, no. 62 , $85 p$.

Cook, P.J. and Shergold, J.H. (eds.), 1986. Phosphate deposits of the World - Volume 1 Proterozoic and Cambrian Phosphates. Cambridge University Press, 560p.

Crandall, D.R., Booth, B., Kusumadinata, K., Shimozuru, D., Walker, G.P.L. and Westercamp, D., 1984. Source-Book for Volcanic-Hazards Zonation. Unesco Natural Hazards Series 4, Paris, 97p.

Hein, J.R., 1987. Siliceous sedimentary rockhosted ores and petroleum. Van Nostrand Reinhold, New York, 320p.
Petrascheck, W., Karamata, S., Kravchenko, G.G., Johan, Z., Economou, M. and Engin, T. (eds.), 1986. Chromites. Theophrastus Publications, Athens, $339 \mathrm{p}$.

Reyment, R.A., and Bengston, P. (eds.), 1986. Events of the Mid-Cretaceous. Pengamon Press, 213 .

Šibrava, V., Bowen, D. and Richmond, G. (eds.), 1987. Quaternary Glaciations in the Northern Hemisphere. Quaternary Seience Reviews, no. 5, Pergamon Press, 514p.

Sigvaldason, G.E., 1981. World Organization of Volcano Observatories. Episodes, v. 1981 , no. 4 , p. 9-10.

UNDRO-Unesco, 1985. Voleanic Emergency Management. United Nations, New York, 86p.

Unesco, 1980. IGCP Catalogue, 1973-1979. International Geological Correlation Programme. Unesco, Paris, 184p.

Unesco, 1983. Science, Resources and Developing Nations - A Review and Look into the Future - 1978-1982. (International Geological Correlation Programme) Geological Correlation, Special Issue. Unesco, Paris, 166p.

Unesco, 1983. IGCP Catalogue II, 1978-1982. International Geological Correlation Programme. Unesco, Paris, 790p.
Unesco, 1984. Ground-Water in Hard Rocks. Unesco Studies and Reports in Hydrology, no. 33 , Paris, 228p.

Unesco, 1986. IGCP Catalogue III, 1983-1985. International Geological Correlation Programme. Unesco, Paris, 150p.

Unesco, 1987. Man's Dependence on the Earth: The Role of the Geosciences in the Environment. UNEP, Nairobi; Unesco, Paris; Schweizerbart'sche Verlagsbuchhandlung, Stuttgart, 213 p.

Unesco/IAHS, 1981. Avalanche Atlas: Illustrated International Avalanche Classification. English/French/Spanish/ Russian/German. International Association of Hydrological Sciences and Unesco, Natural Hazards Series 2, Paris, 265p.

van de Plassche, O. (ed.), 1986. Sea-level research: A manual for the collection and evaluation of data. Geobooks, Norwich, U.K., 620 p.

Varnes, D.J., 1984. Landslide Hazard Zonation: A Review of Principles and Practice. Unesco Natural Hazards Series 3, Paris, 64p.

Weber, C.C., 1981. Seismic hazards in the Mediterranean. Episodes, v. 1981, no. 1, p. 16-18. 